\begin{tabular}{|c|c|c|}
\hline \multicolumn{3}{|c|}{ PublisherInfo } \\
\hline PublisherName & & BioMed Central \\
\hline PublisherLocation & & London \\
\hline PublisherImprintName & & BioMed Central \\
\hline
\end{tabular}

130591474-760XGenome BiologyGenome BiolLife SciencesAnimal Genetics and GenomicsHuman GeneticsPlant Genetics \& GenomicsMicrobial Genetics and GenomicsBioinformaticsEvolutionary BiologyBiomedical and Life Sciences441211292

CoverDate : 2003-12-

The Author(s)2003

\title{
All that antisense
}

\begin{tabular}{|l|l|l||}
\hline \multicolumn{2}{|c|}{ ArticleInfo } \\
\hline \hline ArticleID & $:$ & 4726 \\
\hline \hline ArticleDOI & $:$ & $10.1186 /$ gb-spotlight-20030319-01 \\
\hline \hline ArticleCitationID & $:$ & spotlight-20030319-01 \\
\hline \hline ArticleSequenceNumber & $:$ & 78 \\
\hline \hline ArticleCategory & $:$ & Research news \\
\hline ArticleFirstPage & $:$ & 1 \\
\hline \hline ArticleLastPage & $:$ & 2 \\
\hline \hline & & RegistrationDate : 2003-3-19 \\
\hline ArticleHistory & $:$ & OnlineDate \\
\hline \hline ArticleCopyright & $:$ & BioMed Central Ltd2003-19 \\
\hline \hline ArticleGrants & $:$ & \\
\hline \hline ArticleContext & $:$ & 130594411 \\
\hline \hline
\end{tabular}




\section{Jonathan B Weitzman}

Email: jonathanweitzman@hotmail.com

Only a few examples of antisense transcripts have been extensively characterized in the human genome and they are often associated with imprinted loci. In an Advanced Online Publication in Nature Biotechnology Rodrigo Yelin and colleagues at Compugen Ltd in Israel propose that regulation by antisense transcription may be quite frequent (Nature Biotechnology, 17 March 2003, doi:10.1038/ nbt808). They used a computational approach (the 'Antisensor' algorithm) to identify 2,667 human genomic loci with evidence of transcripts from both strands. Microarray analysis with strand-specific oligonucleotide probes demonstrated that as many as $60 \%$ of these may be true sense-antisense pairs. This places the number of possible antisense-regulated genes much higher than previous estimates.

\section{References}

1. Noncoding RNA genes in dosage compensation and imprinting

2. Nature Biotechnology, [http://www.nature.com/naturebiotechnology]

3. Compugen Ltd, [http://www.compugen.co.il]

4. Antisensor, [http://www.labonweb.com/antisense]

5. Raw data, [http://www.labonweb.com/antisense/Raw_Data]

6. Computational discovery of sense-antisense transcription in the human and mouse genomes. 